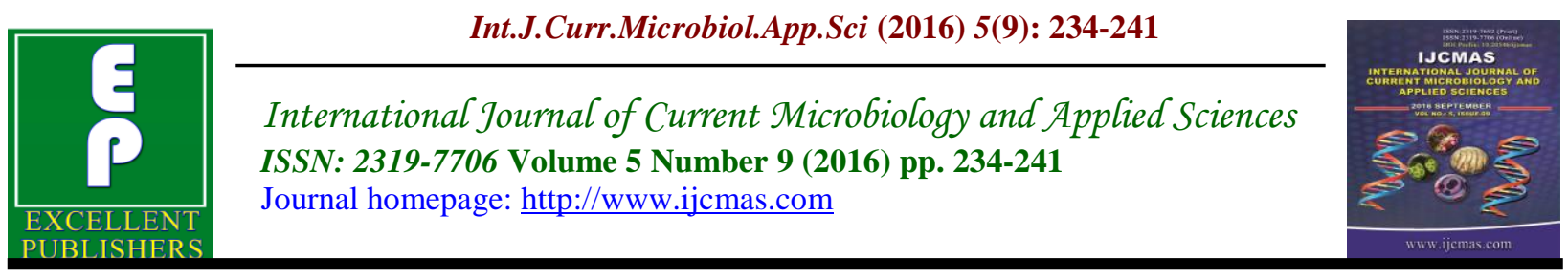

Original Research Article

http://dx.doi.org/10.20546/ijcmas.2016.509.026

\title{
Antibiotic Properties of Aqueous and Methanol Extracts of Acalypha ciliata Leaves
}

\author{
C.A. Anosike*, O.F.C. Nwodo and E.B. Amadi \\ Department of Biochemistry, University of Nigeria, Nsukka, Enugu State, Nigeria \\ *Corresponding author
}

Keywords

Antibacterial activity, Acalypha ciliata, microorganism, Colony forming unit, MIC.

\begin{tabular}{l}
\hline Article Info \\
\hline Accepted: \\
13 August 2016 \\
Available Online: \\
10 September 2016
\end{tabular}

\section{A B S T R A C T}

This study demonstrated the antibiotic properties of aqueous and methanol extracts of Acalypha ciliata leaves. This was carried out using both gramnegative and gram-positive bacteria which included Pseudomonas aeruginosa, Escherichia coli, Staphylococcus aureus, Salmonella typhi, Proteus mirabilis, Klebsiella pneumonia, and Streptococus pyrogenes. The aqueous extract of Acalypha ciliata leaves showed antibacterial activity ranging from 8.00 $17.00 \pm 2.00 \mathrm{~mm}$, while that of methanol extract was from $9.00-20.00 \pm 4.00 \mathrm{~mm}$. The duration of antibacterial activity observed in aqueous extract ranged from $5.00-11.00 \pm 2.00$ days, while that of methanol extract ranged from $5.00-$ $12.00 \pm .00$ days. The minimum inhibitory concentrations (MIC) of both methanol and aqueous extracts against the test bacteria were between $6.25-$ $12.50 \pm 0.00 \mathrm{mg} / \mathrm{ml}$. However, the minimum bactericidal concentration (MBC) of both aqueous and methanol ranged from $9.38-25.00 \pm 0.00 \mathrm{mg} / \mathrm{ml}$. The result of colony forming unit (CFU) showed that Klebsiella pnumoniae had the highest CFU value of $4.15 \pm 0.04 \times 10^{8} \mathrm{cfu} / \mathrm{ml}$ while Proteus mirabilis had the least CFU of $1.27 \pm 0.06 \times 10^{8} \mathrm{cfu} / \mathrm{ml}$. This research indicates that extracts of Acalypha ciliata leaves has broad spectrum antibacterial properties.

\section{Introduction}

Bacteria constitute a large domain of prokaryotic microorganisms. They inhabit soil, water, hot springs, radioactive waste, and deep portions of earth's crust (Fredrickson et al., 2004). Bacteria also live in plants and animals. Bacteria resistance to antimicrobial drugs has continued to grow in the last decades (Nascimento et al., 2000). This increase is due to long term over-use or under-utilization of the previously existing antibiotics - drug abuse. Bacteria develop a mechanism of overcoming the toxic effects of these antibiotics by producing antitoxins that neutralize the effect of antibiotics. This has rendered the current available antimicrobial agents insufficient to control microbial infections (Cowan, 1999), and thus create major public health problems (Bax and Mullan, 2000). Therefore, there is need for development of new and broad- 
spectrum antibacterial agents or drugs to curb this menace of bacterial resistance and infectious diseases. Acalypha ciliata, Indian nettle (family: Euphobiaceae) is considered by traditional practitioners to possess expectorant, purgative, emetic, gastrointestinal irritative and diuretic properties (Aryavaidya and Warrier, 2005). This study was therefore designed to assess the antibiotic properties of the aqueous and methanol extracts of Acalypha ciliata leaves.

\section{Materials and Methods}

\section{Collection of plant material}

The leaves of Acalypha ciliata were collected from Opi in Nsukka Local Government of Enugu state, Nigeria. The leaves were identified by Mr. Alfred Ozioko of Bioresources Development and Conservation Programme (BDCP) Nsukka, Nigeria.

\section{Extraction of plant material}

A quantity, $656 \mathrm{~g}$ of the dried pulverized leaves was macerated in 3.28 liters of chloroform and methanol in the ratio of $2: 1$ respectively for $24 \mathrm{~h}$. The solution was filtered with Whatman filter paper and a volume of water equivalent to $20 \%$ of the volume of the filtrate was added to the filtrate. The filtrate was suspended in a separating funnel and the upper (methanol) layer was collected and then concentrated at $64^{\circ} \mathrm{C}$ using a water bath (Folch et al., 1954). Aqueous extract was obtained by soaking $100 \mathrm{~g}$ of pulverized leaves in $500 \mathrm{ml}$ of water for $24 \mathrm{~h}$. This was filtered with Whatman No 1 filter paper and the filtrate was concentrated in a water bath at $100^{\circ} \mathrm{C}$. A stock concentration of $200 \mathrm{mg} / \mathrm{ml}$ was prepared by dissolving $1.0 \mathrm{~g}$ of extract in $5 \mathrm{ml}$ of dimethyl sulfoxide (methanol extract) or in $5 \mathrm{ml}$ of distilled water (aqueous extract).

\section{Bacteria species}

Staphilococcus aureus, Klebsiella pneumonia, Escherichia coli, Salmonella typhi, Proteus mirabilis, Pseudomonas aeruginosa and Streptococus pyrogenes. These test microorganisms were obtained from the stock cultures of Department of Microbiology, University of Nigeria Nsukka, Nigeria.

\section{Preparation of test organisms}

Inoculum of size $10^{8}$ colony forming unit per milliliter $(\mathrm{cfu} / \mathrm{ml})$ of each of the isolates was prepared according to the method described by Bauer et al., (1966). This was done by suspending loopful of inoculums from stock into test tubes containing $5 \mathrm{ml}$ of nutrient broth and incubated at $37^{\circ} \mathrm{C}$ for 24 h. The resultant culture was diluted with fresh nutrient broth in order to achieve optical density corresponding to $10^{8} \mathrm{cfu} / \mathrm{ml}$. This was repeated for all the bacteria used in the study.

\section{Sensitivity test}

Agar Well diffusion method was used. The plates were seeded with $24 \mathrm{~h}$ old cultures of the isolates and wells of $7 \mathrm{~mm}$ diameter were dug in nutrient agar plates. In each well, $150 \mu \mathrm{l}$ of the dissolved extracts (from prepared stock above) was used to fill the hole. A standard drug (Chloramphenicol, $150 \mu \mathrm{l})$ was also used, while dimethyl sulphoxide and distilled water were used as the negative controls. The plates were incubated at $37^{\circ} \mathrm{C}$ for $24 \mathrm{~h}$. Antibacterial activity was determined by measuring the diameter of the inhibition zone formed around the well by use of a meter rule.

\section{Minimum inhibitory concentration (MIC)}

This test was performed using double dilution techniques according to Sidney et 
al., (1978) and Vollekova et al., (2001) which followed the National Committee for Clinical Laboratory Standard (NCCLS) guidelines on MIC (2001). The two-fold serial dilution of the plant extracts were carried out in nine test tubes. For each bacterial isolate, 9 test tubes were serially arranged for the double dilution, and $0.1 \mathrm{ml}$ of each of these varying concentrations of the extracts (tubes 1-9) was separately added into each of another serially arranged nine test tubes containing $0.3 \mathrm{ml}$ of sterile broth. Finally, each tube was inoculated with $0.1 \mathrm{ml}$ of the standardized suspension of the test bacteria. The last test tube (tube 10) which served as control contained only bacteria suspension and sterile broth. The test tubes were incubated at $37^{\circ} \mathrm{C}$ for $72 \mathrm{~h}$. The least concentration of the extract with no visible growth (turbidity) was chosen as the MIC. Turbidity was assessed using spectrophotometer at $500 \mathrm{~nm}$.

\section{Minimum bactericidal concentration (MBC)}

This was determined by broth dilution resulting from the MIC tubes, by subculturing to antimicrobial free agar as described by Vollekova et al., (2001). In this technique, the contents of the tubes resulting from MIC was streaked, using a sterile wire loop, on agar plate free of bacteria and incubated at $37^{\circ} \mathrm{C}$ for $48 \mathrm{~h}$. The lowest concentration of the extract which showed no bacteria growth was noted and recorded as the minimum bactericidal concentration (MBC).

\section{Duration of antibacterial activity}

Duration of antibacterial activity was determined by checking the time it took the test bacterium to grow back to the zone of inhibition in the sensitivity test.

\section{Colony forming unit (CFU)}

The spread plate method of Miles et al., (1938) as reported by Gilchrist et al., (1977) was used. The sample $(10 \mu l)$ was spread across the surface of a nutrient agar plate and allowed to air- dry before incubating for counting. Extract $(10 \mu \mathrm{l})$ was dissolved in $990 \mu 1$ of normal saline (dilution factor 1/100). This step was repeated again and $10 \mu \mathrm{l}$ resulting from the last dilution was further dissolved in $190 \mu$ l of normal saline. Finally, $10 \mu 1$ of the last dilution was spread across the surface of sterile agar plate and incubated for $24 \mathrm{~h}$ before counting. The total dilution factor used were $1 / 100,1 / 100,1 / 20$, $1 / 10$. These experiments were performed in triplicate.

\section{Results and Discussion}

The result of this study as presented in table 1 show that the highest zone of inhibition against the test organisms was exhibited by Chloramphenicol, except against E-coli, where the inhibition exhibited by the extracts against E-coli were comparable to that by the standard drug. The aqueous extract showed the least inhibition (8.00 \pm $0.58 \mathrm{~mm}$ ) against Klebsiella pneumoniae while the highest inhibition (17.00 \pm $1.16 \mathrm{~mm}$ ) was observed against Staphylococcus aureus. For the methanol extract, the highest inhibition observed was against Streptococcus pyrogenes, (20.00 \pm $2.31 \mathrm{~mm}$ ), while the lowest inhibition observed was against Klebsiella pneumoniae, $(9.00 \pm 0.58 \mathrm{~mm})$ (table 1$)$. The MIC result showed that the least concentration of extracts (aqueous and methanol) that could inhibit growth of bacteria was $6.25 \mathrm{mg} / \mathrm{ml}$ while the least concentration of the standard drug (Chloramphenicol) was recorded against Salmonella typhi at $0.78 \mathrm{mg} / \mathrm{ml}$. Higher concentration was observed for methanol 
extract against Pseudomonas aeruginosa and Salmonella typhi than that of the aqueous extract (fig.1). The least bactericidal concentration of aqueous and methanol extracts was $9.38 \mathrm{mg} / \mathrm{ml}$ (fig. 2). The minimum bactericidal concentration (MBC) was detected in aqueous extract against Klebsiella pneumonia $(9.38 \mathrm{mg} / \mathrm{ml})$. Duration of antibacterial activity in both extracts ranged from 5-13 days (Table 2). Methanol extract showed the highest duration of antibacterial activity against Pseudomonas aeruginosa (13 days) and the least duration against Salmonella typhi (5 days), while aqueous extract showed the highest antibacterial duration against Proteus mirabilis (11 days) and least duration against Klebsiella pneumoniae (5 days).

The result of colony forming unit (CFU) indicated that Klebsiella pneumoniae had the highest number of viable cells of $4.15 \pm$ $0.2 \times 10^{8} \mathrm{Cfu} / \mathrm{ml}$ while Proteus mirabilis had the least number of cells $(1.27 \pm 0.3 \times$ $10^{8} \mathrm{Cfu} / \mathrm{ml}$ ) (fig. 3).

Over the last decades, there has been a lot of work in the area of elucidating the active principle of herbal medicines and synthesizing the active constituent for medical use. Research has shown that a number of potent herbs do not show activity or show reduced activity after separation and synthesis of the active principle (Otimenyin et al., 2008). This largely has been attributed to the fact that some of the bioactive components in plants act synergistically or inhibit the actions of other components in the plant. The use of whole plant material as drug has been supported by this research.

The aqueous and methanol extracts of Acalypha ciliata leaves exhibited antibacterial activity against a wide variety of bacteria. This result is in agreement with the findings of Thenmozhi and Rajan, (2012) on the antibacterial properties of the leaf extract of Acalypha indica linn, a related specie to Acalypha ciliata. The sensitivity result in this study supports the findings of Oladunmoye (2006); Jigam et al., (2004); Farnaz et al., (2010) and Otimenyin et al., (2008) who reported the antimicrobial activity of several medicinal plants against $E$-coli, $P$ mirabilis, $P$ aeruginosa, $S$ aureus, $S$ typhi and $K$ pneumoniae.

Table.1 Sensitivity test of extracts of Acalypha ciliata leaves (zones of inhibition in mm)

$\begin{array}{llll}\text { Bacteria } & \text { Aqueous extract }(\mathrm{mm}) & \text { Methanol extract }(\mathrm{mm}) & \text { Chloramphenicol(mm) } \\ \text { Pseudomonas aeruginosa } & 8.33 \pm 0.88 & 18.00 \pm 2.31 & 28.00 \pm 2.31 \\ \text { Escherichia coli } & 13.00 \pm 1.73 & 13.00 \pm 1.73 & 13.00 \pm 1.00 \\ \text { Staphylococcus aureus } & 17.00 \pm 1.16 & 15.00 \pm 1.15 & 23.00 \pm 1.15 \\ \text { Salmonella typhi } & 10.00 \pm 1.73 & 9.67 \pm 0.67 & 14.33 \pm 2.96 \\ \text { Proteus mirabilis } & 15.00 \pm 2.89 & 13.00 \pm 2.89 & 22.33 \pm 4.10 \\ \text { Klebsiella pneumonia } & 8.00 \pm 0.58 & 9.00 \pm 0.58 & 15.00 \pm 0.58 \\ \text { Streptococcus pyrogenes } & 16.00 \pm 2.31 & 20.00 \pm 2.31 & 19.95 \pm 2.31\end{array}$


Table.2 Duration of antibacterial activity (days)

\begin{tabular}{llll}
\hline Bacteria & Aqueous extract (days) & Methanol extract(days) & Chloramphenicol(days) \\
Pseudomonas aeruginosa & $7.00 \pm 1.73$ & $13.00 \pm 1.73$ & $14.00 \pm 1.18$ \\
Escherichia coli & $8.00 \pm 1.16$ & $8.00 \pm 1.55$ & $7.00 \pm 1.15$ \\
Staphylococcus aureus & $9.00 \pm 1.16$ & $10.00 \pm 1.55$ & $13.00 \pm 1.15$ \\
Salmonella typhi & $5.00 \pm 0.00$ & $5.00 \pm 0.00$ & $7.00 \pm 0.00$ \\
Proteus mirabilis & $11.00 \pm 1.56$ & $7.00 \pm 1.55$ & $10.00 \pm 1.15$ \\
Klebsiella pneumonia & $5.00 \pm 1.56$ & $7.00 \pm 1.55$ & $10.00 \pm 1.15$ \\
Streptococcus pyrogenes & $9.00 \pm 0.58$ & $12.00 \pm 0.58$ & $14.00 \pm 0.58$ \\
\hline
\end{tabular}

Fig.1

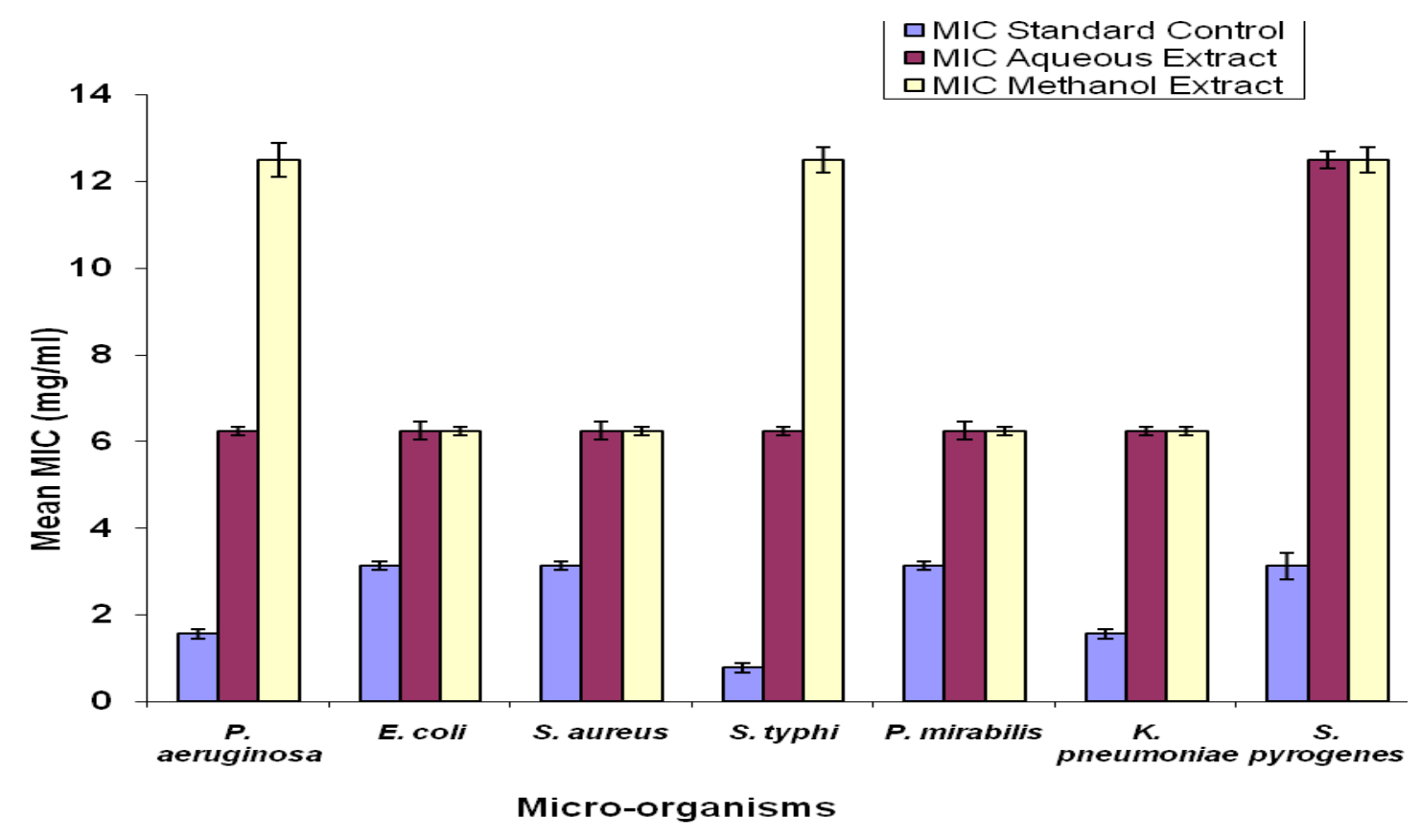

Fig. 1: Minimum inhibitory concentration of aqueous and methanol extracts of Acalypha cillata leaves 
Fig.2

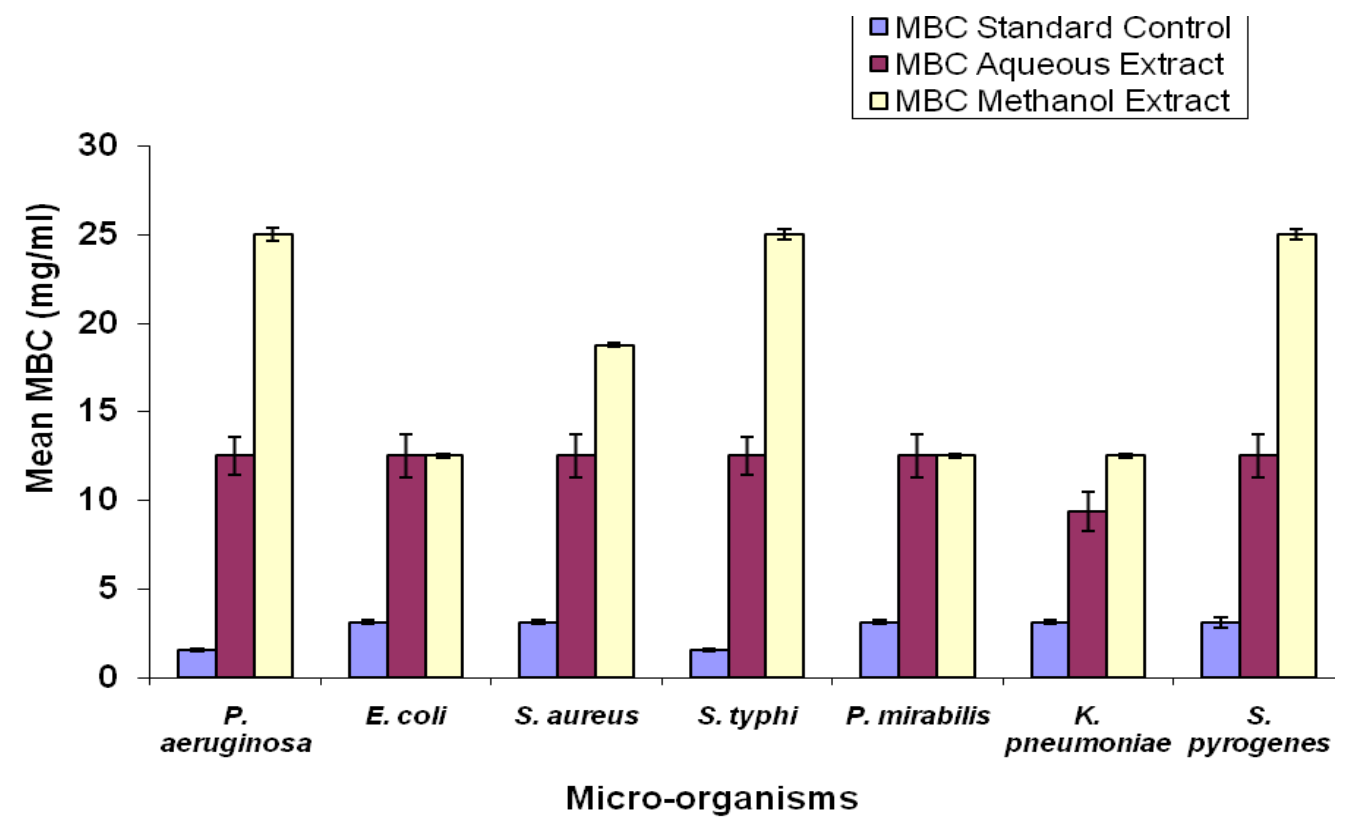

Fig. 2: Minimum bactericidal concentration of aqueous and methanol extracts of Acalypha ciliata leaves

Fig.3

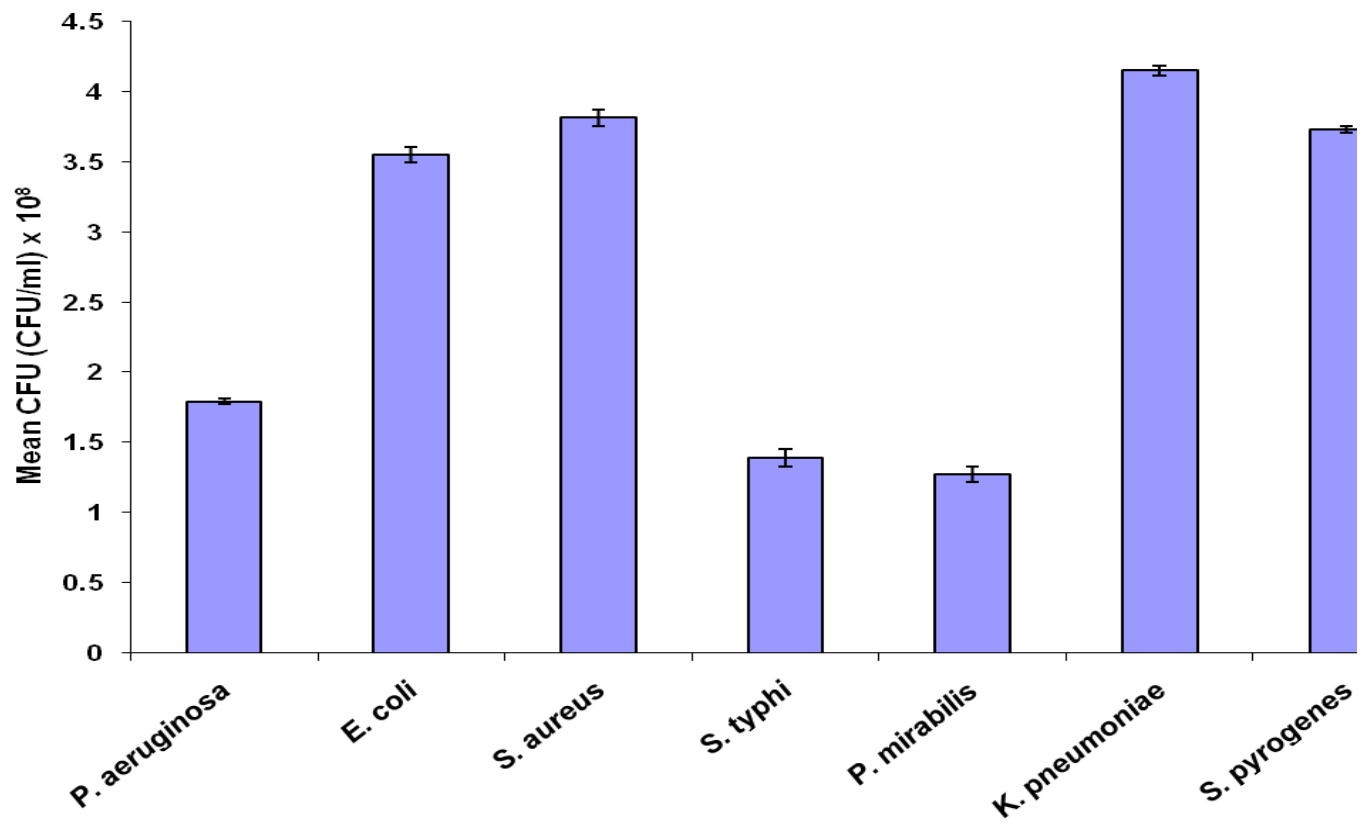

Fig. 3: Colony forming unit (CFU) of bacteria 
This study shows that Acalypha ciliata extracts (aqueous and methanol) have potent antibacterial activity against Pseudomonas aeruginosa, Salmonella typhi, Staphylococcus aureus and Klebsiella pneumoniae. Variation in antibacterial activity may occur due to variation in phytochemical contents as a result of different geographical locations in which the plants were collected.

The minimum inhibitory concentration (MIC) and minimum bactericidal concentration (MBC) of this study also agree with the work of Idu et al., (2013) which showed the MIC against Escherichia coli and Staphylococcus aureus at similar concentration with that obtained in this work. It was also observed that Acalypha ciliata leaf extract inhibited the growth of Pseudomonas aeruginosa, at the concentration of $12.5 \mathrm{mg} / \mathrm{ml}$ which was less than $25.0 \mathrm{mg} / \mathrm{ml}$ recorded against Pseudomonas aeruginosa by the ethanol extract of Dacryodes edulis leaves as reported by Idu et al., (2013). Acalypha ciliata extracts showed higher MIC and MBC values against Pseudomonas aeruginosa and Salmonella typhi than the ethanol extract of Acalypha wilkesiana as was recorded by Gotep et al., (2010). This implies that Acalypha wilkesiana has more antibacterial activity than Acalypha ciliata against these two bacteria.

This study has shown that MBC values are higher than MIC values (Fig.1 and 2). This indicates that the concentration of Acalypha ciliata leaf extracts required to kill bacteria is more than the concentration required toinhibit bacterial growth. Since Acalypha ciliata leaf extracts have antibacterial activity against Pseudomonas aeruginosa, Escherichia coli, Staphylococcus aureus, Salmonella typhi, Proteus mirabilis, Klebsiella pneumoniae and Streptococcus pyrogenes, it could therefore be used for the treatment of various diseases such as boils, pneumonia, typhoid fever, respiratory and urinary tract diseases, skin rashes, wound infection, nonbullous impetigo and urethritis where these bacteria are the causative microorganisms.

In conclusion, report from this study suggests that Acalypha ciliata leaf extract is a broad spectrum antibiotic extract that has its antibacterial activity on both gram negative and gram positive bacteria. Therefore it can be useful for the treatment of various bacterial infections that have developed resistance to the existing antibiotics.

\section{References}

Aryavaidya, S.K. and Warrier, P.K. 2005. Indian medicinal plants: a compendium of 500 species. Volume 4 orient longman Hyderabad. Pp 36.

Bauer, A.W., W.M. Kirby, J.C. Sherris and Turk, M. $1966 . \quad$ Antibiotic susceptibility by a standardized single disk method. American J. Clin. Pathol., 45(4): 493- 496.

Bax, R. and Mullan, V. 2000. The millennium bugs-the need for and development of new antibacterials. Int. J. Antimicrobial Agent, 16: 51-59.

Cowan, M.M. 1999. Plant products as antimicrobial agents. Clin. Microbiol. Rev., 12: 564-582.

Farnaz, M., M. Tashira, R.. Humayun, H. Abdule and Shahzad, H. 2010. Biological screening of seventeen medicinal plants used in the traditional systems of medicine in Parkistan for antimicrobial activities. African $J$. Pharmacy and Pharmacol., 4(6): 335340.

Folch, J., M. Lees and Sloane -Stanley, G.H. 1954. A simple method for the isolation and purification of total lipids 
from animal tissues. J. Biol. Chem., 226: 497-509.

Fredrickson, J.K., J.M. Zachara and Balkwill, D.L. 2004. Geomicrobiology of high-level nuclear wastecontaminated vadose sediments at the Hanford site, Washington State. Appl. Environ. Microbiol., 70(7): 42304241.

Gilchrist, J.E., C.B. Donnelly, J.T. Peeler and Campbell, J.E. 1977. Collaborative study comparing the spiral plate and aerobic plate count methods. J, Assoc, Officials of Anal, Chem., 60: 807-812.

Gotep, J.G., G.O.A. Agada, D.S., Gbise and Chollom, S. 2010. Antibacterial activity of ethanolic extract of Acalypha wilkesiana leaves growing in Jos, Nigeria. Malaysian $J$. Microbiol., 6(2): 69-74.

Idu, M., J.O. Erhabor and Towuru, G.E. 2013. Antimicrobial effect of chloroform and ethanolic leaf extracts of Dacryodes edulis, Garcina kola and Chrysophyllum albidum on test isolates. Med. Sci., 1(3): 63-66.

Jigam, A.A., H.O. Akanya, and Adeyemi, D.J. 2004. Antibacterial and antiplasmodial effects of Momordica balsamina. Nigerian J. Natural Product Med., 8: 11-12.

Miles, A.A., S.S. Misra and Irwin, J.O. 1938. The estimation of the bactericidal power of the blood. The $J$. Hygiene, 38(6): 732-749.

Nascimento, G.F., L. Juliana, C.F. Paulo and
Giuliana, L.S. 2000. Antibacterial activity of plant extracts and phytochemicals on antibiotic resistance bacteria. Braz. J. Microbial, 31: $247-256$.

NCCLS. 2001. Methods for dilution in antimicrobial susceptibility tests for bacteria that grow aerobically. $2^{\text {nd }}$ edn., Approved Standard. NCCLS Document M7-A2 (M100-S4).

Oladunmoye, M.K. 2006. Comparative evaluation of antimicrobial activities and phytochemical screening of two varieties of Acalypha wilkesiana. Trends in Appl. Sci. Res., 1: 538-541.

Otimenyin, S.O., M.O Uguru and Ogbonna, A. 2008. Antibacterial and hypoglycemic effects of Momordica balsamina.Linn. J. Natural Products, 1: 03 - 09.

Sidney, M.F., J.M. William and Elvyn, G.S. 1978. Barley and Scotts Microbiology, C.V Moshy. Pp: 385-403.

Thenmozhi, S. and Rajan, S. 2012. Screening of antibacterial and phytochemical activity of Acalypha indica linn against isolated respiratory pathogens. Res. Plant Biol., 2(1): 0106.

Vollekova, A.D., C. Kostalova and Sochorova, R. 2001. Isoquilonine alkaloids from Mahonia aquifolium stem bark as active agent against malassezia species. Folia Microbiol., 46: $107-111$.

\section{How to cite this article:}

Anosike, C.A., O.F.C. Nwodo and Amadi, E.B. 2016. Antibiotic Properties of Aqueous and Methanol Extracts of Acalypha ciliata Leaves. Int.J.Curr.Microbiol.App.Sci. 5(9): 234-241. doi: http://dx.doi.org/10.20546/ijcmas.2016.509.026 